Volume 5 Number 1, January-June 2021: pg. 53-64.

Fakultas Hukum, Universitas Lampung,

Bandar Lampung, Lampung, Indonesia.

E-ISSN: 2598-3105 P-ISSN: 2723-2581

http://jurnal.fh.unila.ac.id/index.php/cepalo

\title{
PERSPECTIVE OF RELIGIOUS JUSTICE IN THE FORMULATION OF PENAL REFORM
}

\author{
Reski Anwar', Faisal $^{2}$, Rio Amanda Agustin ${ }^{3}$ \\ ${ }^{1}$ Institut Agama Islam Negeri Syaikh Abdurrahman Siddik Bangka Belitung, \\ Email: Reskibelitong@gmail.com \\ ${ }^{2}$ Universitas Bangka Belitung, Email: progresif_1shp@yahoo.com \\ ${ }^{3}$ Universitas Bangka Belitung, Email: rioarmanda.agustian@yahoo.com
}

Submitted: March 2, 2021; Reviewed: March 10, 2021; Accepted: March 25, 2021

DOI: 10.25041/cepalo.v5no1.2240

\begin{abstract}
The perspective of justice from law enforcement is only on the law's guidance, not based on God's guidance that prioritizes substantive justice. The idea of religious justice contained in the renewal of criminal law there is Article 53 paragraph (2), with the provision reads in considering the establishment of law and justice as referred to in paragraph (1) there is a conflict that can not be met, the judge must prioritize justice. The recommendations are stated because the explanation of Article 53 paragraph (2) says that justice and legal certainty are two legal objectives that are often not in line with each other and difficult to avoid in legal practice. A rule of law that meets more legal certainty demands, the more likely aspects of justice are urged. Metode research used in this study is normative research, namely research on library materials that are essential data that is classified as secondary data that rests on data collection tools similar to literature studies or document studies. The results showed that if in the application of concrete events, justice and legal certainty are mutually urgent, then the judge, as far as possible, prioritizes justice over legal certainty. Religious Justice that exists in the value of Pancasila formulated into the renewal of criminal law justice contains a demand that people treat others following their rights and obligations. The treatment is not indiscriminate or compassionate; instead, everyone is treated equally under their rights and responsibilities.
\end{abstract}

Keywords: Justice, Religious, Penal Reform

\section{A. Introduction}

The nature of normative in law mainly discusses the conception of social insight, which has a context in Indonesia the meaning of national law, which means normative science about the concept of social life in the Republic of Indonesia's territory. Suppose you want to be juxtaposed with what is in the preamble of the 1945 Constitution. In that case, it is said that Indonesian Law Science is a knowledge of the procedures for life covering various aspects of the nation and be it ideology, politics, economy, social, defence and security or Ideology, Politik, Ekonomi, Sosial, Pertahanan dan Keamanan (IPOLEKSOSBUDHANKAM). The 
process of drafting a new KUHP to reconstruct the KUHP left by the colonialists with various forms of changes is an effort to develop national law (criminal law). ${ }^{1}$ Of course, these efforts are carried out with a very long process to adapt to the current legal development conditions and pay attention to awareness of the law with the dynamics developing in the community.

Recent developments mean the renewal of the national RKUHP, which was initially led to a single mission. ${ }^{2}$ Of course, it contains the meaning of decolonization of the Criminal Code in the form of recodification, in the course of the nation's history, in the end, it also contains a wider variety of missions concerning both national and international developments. The second point is the mission of democratizing criminal law. ${ }^{3}$; in a broad sense, it wants to consider infrastructural, superstructural aspirations, expertise, and international aspirations. As a note, it can be argued that colonial influence in criminal law occurs systematically through the Dutch courts' concordance, doctrine, and jurisdiction principles. As long as it is related to international aspirations, in this case, it can be in the form of standards, principles, and values, and norms, whether they are still "soft law" in the "enunciative, declarative, and prescriptive" stages or the form of "hard law" at the stages, which are stages of "enforcement and criminalization".

The third point is the consolidation of criminal law. In this mission, it is planned that since independence in 1945, the existing legal regulations in criminal law have undergone partial changes both inside and outside the Criminal Code with various kinds of transitional rules. Hence, it is indispensable to reconstruct it into a Criminal Law reform. The reformer's conception of criminal law has been reaffirmed regarding changing norms. The reforms carried out will still carry an ideal based on values. Mufatikhatul Farikhah's research is interesting to examine when writing about Judicial Pardon, namely the concept of judge forgiveness, one of the Criminal Code Draft reforms. At the same time, Judicial Pardon will provide two feelings of justice in applying laws and laws: moral justice and law justice. ${ }^{4}$ Moral-based justice is closely related to reform. If there are two concepts between legal justice and legal certainty, legal justice is prioritized.

Because if it only stops on the argument of legal certainty for balance in achieving national interests, it will experience difficulties in its implementation. Legal certainty should not only be one aspect of this goal. According to Jan Michiel Otto, legal certainty does not only follow the certainty of laws or norms themselves. ${ }^{5}$

Criminal reform in the Criminal Code concept also provides significant changes to the future criminal justice system. The punishment's orientation is no longer merely retaliating against the perpetrator's actions, but there are also efforts to correct and educate the perpetrator. Conservative thinking puts forward the provision of punishment in punishment for crimes committed as a form of retaliation. Meanwhile, the basic idea in the rehabilitation concept is that if the perpetrator of a crime has committed a predetermined violation, the

\footnotetext{
1 Muhammad Rustamaji, "BIOMIJURIDIKA: PEMIKIRAN ILMU HUKUM PIDANA BERKETUHANAN DARI BARDA NAWAWI ARIEF”, Undang: Jurnal Hukum 2, no. 1 (2019): 193-223, 199, DOI: https://doi.org/10.22437/ujh.2.1.193-223

${ }^{2}$ Explanation of the 2019 Draft New Criminal Code.

${ }^{3}$ Explanation of the 2019 Draft New Criminal Code.

${ }^{4}$ Mufatikhatul Farikhah, "KONSEP JUDICIAL PARDON (PEMAAFAN HAKIM) DALAM MASYARAKAT ADAT DI INDONESIA”, Jurnal Media Hukum 25, no. 1 (2018): 81-92, 83, DOI: 10.18196/jmh.2018.0104.8192.

5 Faisal, Rustamaji, "PERSPEKTIF HUKUM PIDANA DALAM POLEMIK PENGAJUAN SUMPAH ADVOKAT: TELAAH PUTUSAN MAHKAMAH KONSTITUSI NOMOR 35/PUU XVII/2018 ATAS SURAT KETUA MAHKAMAH AGUNG RI NOMOR 73/KMA/HK.01/IX/2015”, Jurnal Hukum Ius Quia Iustum 27, no. 3 (2020): 458-450, 467, DOI: 10.20885/iustum.vol27.iss3.art2.
} 
perpetrator is signalled as a person who has gone astray and must be rehabilitated. ${ }^{6}$ The concept that exists in the drafting process in the form of the RKUHP is carried out based on the fourth point, namely the mission of adaptation and harmonization to various kinds of facts that are happening in the field, both those that occur in the field of criminal law or the development of normas recognized by the international community.

The embodiment of some of these points will be initiated into the form of criminal law politics, which of course, is deemed necessary in the process of drafting criminal law into the form of codification and unification. ${ }^{7}$ Tujuannya sangat mulai guna menegakan kembali konsistensi hukum, menciptakan kebenaran hakiki, keadilan serta kepastian hukum, hal itu ditunjukan dengan memperhatikan ide keseimbangan dengan kepentingan individu dan masyarakat dalam berbangsa dan bernegara yang sesuai dengan konstitusi. The 4 (four) missions that are already evident are fundamental changes in drafting the Criminal Code Bill. This new KUHP Rangcangan recognizes laws that live in the community or better known as customary law. This is to fulfil the essence of justice that lives in the community to create harmony in life. This condition cannot be denied that Indonesia's homeland is still very much dominated by unwritten legal provisions, even though it has become a moral legitimacy in society that is recognized as part of society's law. The community has other measuring tools to determine a criminal act that is tailored to its pluralistic conditions.

The fulfilment of a sense of justice that has lived in society for a long time certainly has specific guidelines and criteria in determining material law/living law which makes it a source of material legality whose orientation does not come out of the Pancasila value as a guide in the nation and state. Moeljatno mentioned ${ }^{8}$ In the Public Lecture at UII Yogyakarta dated September 12, 1963, that in a state based on Pancasila, with the existence of divine precepts, any knowledge that is not juxtaposed with the divine knowledge will not be complete. Moeljatno's view, concluded by Barda Nawawi Arief, that complete legal knowledge in Indonesia should be a godly law. ${ }^{9}$ Oeripan Notohamidjojo ${ }^{10}$ Argues that the jurist's responsibility is to interpret the law by spiritualizing it into the values of justice, truth, honesty, and compassion because juridical scientific assessment must be deep fundamental to religious values.

Sudarto ${ }^{11}$ During the professor's inauguration regarding a dilemma in the reform of the Indonesian criminal system on December 21, 1974, he believed that after the end of the world war, it encouraged changes in society, especially in legal reform, especially criminal law. Criminal law reflects the cultural values of wealthy society in values, morals, and religious morals. It should be said that the criminal law that exists in a nation reflects the civilization of the nation itself. Barda also said that the truth, which is the basis and object of legal (criminal) studies, should be based on the truth from God. ${ }^{12}$. Hazairin ${ }^{13}$ In the Republic of Indonesia,

\footnotetext{
${ }^{6}$ Hariman Satria, "RESTORATIVE JUSTICE: PARADIGMA BARU PERADILAN PIDANA", Jurnal Media Hukum 25, no. 1 (2018): 111-123, 115, DOI: 10.18196/jmh.2018.0107.111-123

7 Otto Yudianto, "KARAKTER HUKUM PANCASILA DALAM PEMBAHARUAN HUKUM PIDANA INDONESIA”, DIH: Jurnal Ilmu Hukum 12, no 23 (2016): 35-44, 40-41, DOI: 10.30996/dih.v12i23.890.

8 Moeljatno, Pidato/Kuliah Umum UII, 12 September 1963, in Barda Nawawi Arief, Ilmu Hukum Pidana Integralistik (Pemikiran Integratif dalam Hukum Pidana), (Semarang: Penerbit Pustaka Magister, 2015), 28.

9 Barda Nawawi Arief, Masalah Penegakan Hukum dan Kebijakan Hukum Pidana dalam Penanggulangan Kejahatan (Jakarta: Penerbit Kencana, 2008), 5.

10 Barda Nawawi Arief, Pendekatan Keilmuan dan Pendekatan Religius Dalam Rangka Optimalisasi dan Reformasi Penegakan Hukum (Pidana) Di Indonesia (Semarang, Badan Penerbit Universitas Diponegoro, 2011), 54.

11 Sudarto, Suatu Dilemma Dalam Pembaharuan Sistim Pidana Indonesia (Semarang: Fakultas Hukum Universitas Diponegoro, 1979), 4.

12 Barda Nawawi Arief, Ilmu Huku Pidana Integralistik (Pemikiran Integratif dalam Hukum Pidana), (Semarang: Penerbit Pustaka Magister, 2015), 29.
} 
nothing that contradicts Islam's principles for Muslims or Christian principles for Christians/Catholics or contradicts the principles of Balinese Hinduism for Balinese Hindus or contradicts their Buddhism honour for Buddhists.

Muladi, ${ }^{14}$ A professor of the inauguration on February 24, 1990, stated that he has the view that in the reform of criminal law, even though the values of Pancasila must be embedded in all the joints of the articles, we should first choose a very strategic aspect in the planned codification structure. The choice of Pancasila values in the above speech is "the only divine value". Barda ${ }^{15}$, In his view that in the concept of criminal law reform, it is necessary to develop a special study regarding the law that lives in a society in the field of criminal law, including unwritten criminal law or customary criminal law. It is worth noting that digging into the living law does not mean simply lifting the customary criminal law into a positive national criminal law. Kembali Barda ${ }^{16}$ emphasized that what should be explored are the similarities in the principles and norms of criminal law contained in living law, from the various similarities in principles and norms that, after being studied and tested by the national value, namely Pancasila, can presumably be elevated to the principles and positive national criminal law norms. ${ }^{17}$

Law enforcers must even be required to have the independence to explore the values that live in the community (local wisdom), of course, to apply the values of justice that will be applied to every decision. Implications If law enforcers are unable to explore the values of justice in society, law enforcement will show failure after failure due to the paralysis of law enforcement's role. ${ }^{18}$ It was assessing and examining the national values of the points of Pancasila, which about the science of godly law, the law is interpreted as a value, namely the divine value that is extracted from the religious values and culture of the Indonesian people, which are in the form of religious values, human values, unity values, democratic values, and the value of social justice. ${ }^{19}$

The main foundation in making law, in this case, legal reform, is based on the Pancasila ideology, which is the foremost guideline in making new laws and by understanding the old law or legal politics, so that divine, human and social values must be actualized into the substance of the law, the legal structure as well as the legal culture that will be built. ${ }^{20}$

Barda Nawai Arief addresses the intellectual conception/basic idea to enforce criminal law by law enforcement officials. That is a law enforcement practice. There is a tendency to think partially in legal thinking, which only looks at criminal laws/provisions with a one-way view or a horse's point of view. The divine value in Pancasila is not only to respect each individual's religion, but it also needs to be understood that it is also rich in values leading to moral paths following Pancasila norms' values. Regarding divine value as a value positioned

\footnotetext{
${ }^{13}$ Hazairin, Demokrasi Pancasila (Jakarta: Bina Aksara, 1985), 34, dalam Barda Nawawi Arief, Pendekatan Keilmuan dan Pendekatan Religius Dalam Rangka Optimalisasi dan Reformasi Penegakan Hukum (Pidana) Di Indonesia (Semarang: Badan Penerbit Universitas Diponegoro, 2011), 54.

${ }^{14}$ Muladi, Proyeksi Hukum Pidana Materiil Indonesia Di Masa Datang (Semarang: Fakultas Hukum Universitas Diponegoro, 1990), 9.

15 Barda Nawawi Arief, Beberapa Aspek Pengembangan Ilmu Hukum Pidana (Menyongsong Generasi Baru Hukum Pidana Indonesia) (Semarang: Fakultas Hukum Universitas Diponegoro, 1994), 13.

${ }^{16}$ Ibid., 27-28.

${ }^{17}$ Yulita Damar Putri, Ni Putu; M.E Purwani, Sagung Putri. "URGENSI PEMBAHARUAN HUKUM PIDANA DI INDONESIA”, Kertha Wicara: Journal Ilmu Hukum 9, no. 8 (2020): 1-13, 1.

${ }^{18}$ Faisal, Menerobos Hukum Positivisme (Yogyakarta: Rangkang-Education, 2010), 80-81.

19 Mahrus Ali, "FONDASI ILMU HUKUM BERKETUHANAN: ANALISIS FILOSOFIS TERHADAP ONTOLOGI, EPISTEMOLOGI, DAN AKSIOLOGI", Pandecta 11, no. 2 (2016): 124-135, 133, DOI: 10.15294/pandecta.v11i2.7844.

20 Derita Prapti Rahayu, “AKTUALISASI PANCASILA SEBAGAI LANDASAN POLITIK HUKUM INDONESIA”, Yustitia 4, no. 1 (2015): 190-202, 200, DOI: 10.20961/yustisia.v4i1.
} 
in the first line, the implementation of this meaning should affect the urgency of divine law, namely, the knowledge that cannot be separated from the value of ilhaiyah. ${ }^{21}$

In principle, a devout criminal law reformer that rests on the meaning of the truth of the word ilhaiyah is fermented into the form of Pancasila in line with the moral and cultural values of the Indonesian nation. Therefore, the essence of truth will be full of effective legal scholarship, not only referring to the truth of correspondence, the truth of coherence, and pragmatic truth but to make the three truths unite under the umbrella of divine truth. Axiology of devoted legal science refers to the ideals of law and the way of life of the Indonesian people, which are reflected in the values of Pancasila. The values in the five principles of Pancasila are the axiology of godly law science, including religious values, humanitarian values, nationalistic-nationalistic/unity values, deliberation values, and social justice values. ${ }^{22}$ The method used in this research is normative juridical research. ${ }^{23}$ The focal point is a comparative study of documents or literature study to collect research data.

The concept of thinking in law enforcement needs a separation between statutory norms and principles, meaningful purposes and values or basic ideas that exist and are recognized in unwritten law, between legal certainty or against formal law with legal certainty against material law, between written law and jurisprudence, law and divinity (moral/religious), many are very knowledgeable about the guidance of the law, but are very ignorant of the meaning of "justice based on the only divine guidance between" the three main problems of criminal law (criminal acts; errors; crimes) and the entire criminal system, between law enforcement (law with the signs of national law enforcement between the criminal law system and the national legal system or Sistem Hukum Nasional (SISKUMNAS).

\section{B. Discussion}

The symposium's implementation in 1980 called for criminal reformers' efforts to inspire national aspirations in legacy or criminal law politics (criminal policy). This means that in making criminal reforms, it must be based on research and a review of comprehensive legal analysis to explore laws that live in society, such as customary criminal law. The nature of law that develops in the community is certainly not free from various religious teachings. Religious teachings are sources of inspiration, motivation, and creative evaluation sources in building legal persons with noble character. The concrete effort must be developed in the content (meaning "source of substance") of national law development policies that can strengthen cultural foundations. Religion facilitates religious development and prevents social conflicts between religious communities. ${ }^{24}$

Various statements regarding the religious-cultural approach or religious culture demand the exploration and realization of values-oriented towards religious morals and social, moral, cultural values, the values of national, local wisdom in the formulation/policy-making of the substance of the criminal law. ${ }^{25}$ The criminal law reform process's real essence is an effort to review and reform the criminal law's strength under the development of Indonesian society's values. Therefore, the exploration of community values to reform Indonesian criminal law

21 Barda Nawawi Arief, Pendekatan Keilmuan dan Pendekatan Religius Dalam Rangka Optimalisasi dan Reformasi Penegakan Hukum (Pidana) Di Indonesia (Semarang: Badan Penerbit Universitas Diponegoro, 2011), 8 .

${ }^{22}$ Mahrus Ali, Loc.Cit.

${ }^{23}$ Soerjono Soekanto dan Sri Mamudji, Penelitian Hukum Normatif (Jakarta: Raja Grafindo Persada, 2004$), 24$.

24 Barda Nawawi Arief, Pendekatan Keilmuan dan Pendekatan Religius Dalam Rangka Optimalisasi dan Reformasi Penegakan Hukum (Pidana) Di Indonesia (Semarang: Badan Penerbit Universitas Diponegoro, 2011), 60.

${ }^{25}$ Ibid., 61. 
must be carried out so that the Indonesian criminal law in the future is following the current conditions of Indonesian society's sociopolitical and sociocultural conditions. ${ }^{26}$

Reform and development of criminal law cannot be carried out partially. However, they must be fundamental, comprehensive, and systematic in recodification, including three main problems of criminal law: the first problem of offence, the second problem of guilt, and the third problem of punishment. These three main problems of criminal law are sub-systems closely related to the general principles of criminal law. In the Draft Criminal Code (as a manifestation of the reform and development of criminal law), the three main problems of criminal law are a sub-system and as well as the pillars of the entire criminal system building, which includes provisions regarding the principles, objectives of the crime/punishment, rules and guidelines for punishment, as well as a general juridical definition relating to the three main problems (crime, guilt, and crime). ${ }^{27}$

Through a doctrinal perspective, the general natured criminal law conception is defined as general principles (Algemene leerstukken Atau Algemene Lehren), such as the problem of criminal acts, the nature of violating the law, mistakes, crimes, and purposes of punishment, principles of criminal law, and so on. Even though seen from the system point of view, the purpose of punishment is very central and fundamental. The purpose of this punishment is the soul and/or spirit of the criminal system. ${ }^{28}$ It needs to be reaffirmed regarding the proper basis for the conviction of an act/crime, which is closely related to the problem of legal sources or legality grounds to declare an act as a criminal act or not. The legality principle formulated in the Draft Criminal Code is expanded materially. An act is a criminal act or not by confirming that this provision (the principle of formal legality) does not diminish the validity of "living law" in society. Thus, in addition to the written law source (statute/formal legality), the Criminal Code Bill expands to unwritten law/material legality.

The existing legality principle recognizes that the source of the legal basis is only the law, which in time will complicate the ideal law enforcement. The expansion of the legality principle in the criminal law reform process in the Draft Criminal Code Book will enact a living law as a source of criminal law. ${ }^{29}$

The development/renewal of the principle of formal legality towards the principle of material legality is formulated in Article 2:

1. The provisions referred to in Article 1 paragraph (1) do not reduce the validity of laws in a society that determines that a person should be sentenced even though it is not regulated in statutory regulations.

2. As referred to in paragraph (1), the law that lives in the community shall apply as long as it follows the values in Pancasila, human rights, and general legal principles recognized by the community of nations.

The elucidation of Article 2 of the Draft Criminal Code is formulated in this paragraph containing guidelines or criteria or guidelines in determining material sources of law (laws that live in society) that can be used as sources of law (sources of material legality). The guidelines in this paragraph are oriented towards Pancasila's values as a source of national law, human rights, general legal principles recognized by the nations' people. Guidelines for

\footnotetext{
${ }^{26}$ Vivi Ariyanti," PEMBAHARUAN HUKUM PIDANA DI INDONESIA YANG BERKEADILAN GENDER DALAM RANAH KEBIJAKAN FORMULASI, APLIKASI, DAN EKSEKUSI", Halu Oleo Law Review 3, no. 2 (2019): 178-195, 181, DOI: 10.33561/holrev.v3i2.8654, See also Tongat, "PANCASILA SEBAGAI DASAR FALSAFAH NEGARA DAN MAKNA FILOSOFISNYA DALAM PEMBAHARUAN HUKUM PIDANA NASIONAL", Masalah-masalah Hukum 41, no. 3 (2012): 399-406, 404, DOI: 10.14710/mmh.41.3.2012.399406.

${ }^{27}$ Barda Nawawi Arief, Kapita Selekta Hukum Pidana (Bandung: Citra Aditya Bakti, 2003), 45-46.

28 Academic Draft Draft Law on Criminal Code (KUHP), Badan Pembinaan Hukum Nasional Kementerian Hukum dan Hak Asasi Manusia Republik Indonesia, (Jakarta Maret 2015), 19-20.

${ }^{29}$ Faisal, Politik Hukum Pidana (Tangerang: Rangkang Education, 2020), 32.
} 
paragraph (2) are oriented towards Pancasila's values as a national law and human rights source. The values in Pancasila are interwoven in a system with the values of the One Godhead, the values contained in the Holy Scriptures.

The criminal law reform is in a new formulation; first, the principle of legality, the second is a criminal act. First, the principle of legality of Article 2 paragraph (1) reads, "The provisions referred to in Article 2 paragraph (1) do not reduce the validity of the law that lives in a society which determines that a person should be sentenced even though the act is not regulated in statutory regulation". The enactment of laws that live in society must also be under the principles of general law recognized by the nations' people (Article 2). It is necessary to conduct a comparative study with the Criminal Code of other countries. General legal principles recognized by the people of nations can be studied from the Armenian Criminal Code, which formulates the principle of legality/principle of legitimacy in Article 5 of the principle of legitimacy:

Article 5 Principle of Legitimacy

1. Only the criminal law decides whether the act is criminal and punishable and other criminal and legal consequences.

2. The application of criminal law by analogy is prohibited.

Article 9. Principle of liability under the offence.

1. The person is subject to criminal liability only for the socially dangerous action or inaction and its socially dangerous consequences, of which he was found guilty by a competent court.

2. Objective incrimination, i.e., criminal liability for infliction of damage without guilt, is prohibited.

However, there are several critical studies by Tody Sasmitha Jiwa Utama regarding the basis of punishment using the living law. The Draft Law on the Criminal Code is based on living laws to impose crimes but ignoring living laws as a basis for reducing punishment or acquiring someone from punishment. This construction risks creating state arbitrariness and giving birth to the duality of customary law. ${ }^{30}$ Faisal revealed that the idea of balance is significant support in making legal, political efforts on the principle of legality by offering a prismatic concept (good balance value). Where the legal prismatic of the legality principle originates from and is oriented towards the balance of the five precepts in Pancasila, which can be condensed into a "balance of three pillars", namely; pillars of divinity (religious), pillars of humanity (humanistic) and pillars of society (nationality, democracy, and social justice). ${ }^{31}$ This balance's basic idea is a choice of law that can have a prismatic concept (good balance value). Given the basic idea of balance, identify combinative options for the values that exist in Indonesian society. ${ }^{32}$

The process to revise the Criminal Code to be close to finalization is very important to include norms per the values of Pancasila as the implementation of a pluralistic and civilized

\footnotetext{
30 Tody Sasmitha Jiwa Utama, "HUKUM YANG HIDUP DALAM RANCANGAN KITAB UNDANGUNDANG HUKUM PIDANA (KUHP): ANTARA AKOMODASI DAN NEGASI”, Masalah-Masalah Hukum 49, no.1 (2020): 14-25, 14, DOI: 10.14710/mmh.49.1.2020.14-25.

${ }^{31}$ Faisal, "MEMBANGUN POLITIK HUKUM ASAS LEGALITAS DALAM SISTEM HUKUM PIDANA INDONESIA" Jurnal Hukum Ius Quia Iustum 21, no. 1 (2014): 81-95, 81, DOI: 10.20885/iustum.vol21.iss1.art5.

${ }^{32}$ K. Maulidah, and N. S. P. Jaya, "KEBIJAKAN FORMULASI ASAS PERMAAFAN HAKIM DALAM UPAYA PEMBAHARUAN HUKUM PIDANA NASIONAL," Jurnal Pembangunan Hukum Indonesia 1, no. 3 (2019): 281-293, 287, DOI: https://doi.org/10.14710/jphi.v1i3.281-293.
} 
national ideology into the criminal law system in Indonesia. ${ }^{33}$ Thus there needs to be a change in the meaning of re-orientation and reformation of Indonesian criminal law, which so far is still based on the principles and philosophical foundations of foreign nations towards a criminal law system based on the philosophy of Pancasila as the values of national and state life aspired to. ${ }^{34}$

The principle of legality in the formulation of the Armenian Criminal Code imposes crimes against crimes formulated in the Criminal Code and against criminal acts and other legal consequences. The formulation of the provisions of Article 9 concerning criminal responsibility and punishment (paragraph 1) is based on the actions and consequences of actions that endanger society. It can be concluded that the Armenian criminal law is based not only on formal legality but also on material legality, namely the socially dangerous action or inaction and its socially dangerous consequences. The second definition of crime in the September 2019 edition of the Draft Criminal Code, the definition of "criminal act" can be understood in the formulation of Part One Criminal Act Paragraph 1 General.

Article 12

1. A criminal act is an act of doing or not doing something, which is punishable by statutory regulations.

2. To be declared a criminal act, an act that is punishable by statutory regulations must also be against the law or contrary to the laws that live in society.

3. Every criminal act is always considered to be against the law unless there is justification for it.

A comparative study of the definition of a criminal act can also be understood from the Armenian Criminal Code, which formulates the definition of a crime in Article 18 below. Article 18. The notion of crime.

1. The willful committal of a socially dangerous act envisaged in this Code is considered a crime.

2. The act or inaction which may formally contain the features of an act envisaged in this Code, but which, however, does not a present public danger because of its little significance, i.e., it did not cause or could not have caused significant damage to an individual or a legal entity, to the society or the state, is not considered a crime.

The formulation of the provisions concerning the definition of "criminal offence" in Article 18 paragraph (1) of the Armenian Criminal Code if an act either does or does not act. First formulated in the Criminal Code. Second, these actions endanger society and are carried out on purpose. Third, these categories can be distinguished between criminal offences in the formal sense and criminal acts in the material sense. Criminal action in a formal sense means that the perpetrator of a criminal act is formulated in the Criminal Code and is carried out on purpose. In contrast, criminal acts in a material sense mean that the perpetrator's actions endanger the community in the formulation of the Draft Criminal Code are contrary to the laws that live in society.

Reski Anwar argues in his research on criminal acts that criminal can be interpreted as a specific meaning related to criminal law. The purpose of this specific definition is that there are various kinds of similarities with general meanings, such as about the sanction of suffering

\footnotetext{
${ }^{33}$ Erfandi, "IMPLEMENTASI NILAI-NILAI PANCASILA DALAM PEMBANGUNAN SISTEM HUKUM PIDANA DI INDONESIA", Jurnal Ilmiah Pendidikan Pancasila dan Kewarganegaraan 1, no 1 (2016): 23-32, 23, DOI: 10.17977/jippk.v1i1.5933.

${ }^{34}$ Sri Endah Wahyuningsih, "URGENSI PEMBAHARUAN HUKUM PIDANA MATERIEL INDONESIA BERDASARKAN NILAI-NILAI KETUHANAN YANG MAHA ESA”, Jurnal Pembaharuan Hukum 1, no. 1 (2014): 17-23, 17, DOI: http://dx.doi.org/10.26532/jph.v1i1.1457.
} 
or sorrow for suffering. This means that an existing act can be categorized as a criminal if the public states that the act is wrong and the regulations govern it. ${ }^{35}$

Such formulation is more limited (endangers the community) than the definition of a criminal act in the Draft Criminal Code, which is more general in nature (contrary to the laws that live in society). In contrast to the formulation of the provisions concerning the definition of "criminal offence" in Article 18 paragraph (1) of the Armenian Criminal Code, formulated in paragraph (2) is not a criminal offence if the conditions are met: (1) Does not cause harm to society because of its minor significance and (2) Does not cause or cannot cause significant damage to individuals or legal entities, society or the state.

Such formulation is the embodiment of a balance between criminal acts based on unwritten/formal law and criminal acts based on written/material law between justification reasons based on written/ formal law (Law) and justification based on unwritten law/material. ${ }^{36}$ Religious justice can be interpreted as justice based on the One Godhead. It needs to be stated in advance about the various views/concepts of thinking about Religious Justice.

Barda Nawawi Arief ${ }^{37}$ As an Expert Member/Selection Committee for Candidates for Supreme Court Justices of the Republic of Indonesia in 2009 argued that it is very ironic, in a country that has One Godhead and the trial is carried out "For Justice based on the One Divinity" however, law enforcement officers only know about justice based on "the guidance of the Act". However, they do not know about justice based on "God's guidance". This guidance of justice from God is clear guidance for quality assurance because God is the Most Just and All-knowing about justice. ${ }^{38}$ Barda emphasized this fairness by citing Khurram Murad's view; "no one can be more merciful or wiser or more just than God Himself". ${ }^{39}$ The rule of justice based on the only divinity, of course, is not only limited to the ability of knowledge but is expected to animate his beliefs and attitudes, that if justice based on divine guidance is not followed and carried out, society will be destroyed.

Bismar Siregar ${ }^{40}$ in one of his lectures at the Faculty of Law, Universitas Sumatera Utara. "If so, is the sentence 'By Justice' also an oath sentence? In my opinion, that is correct! The judges' oath that justice is spoken in the name of God as God's representative, at the same time acts and swears in the name of God". ${ }^{41}$

The sentence of irah-irah is also called by Bismar Siregar as a prayer of a judge, "O God, it is in Your name that I pronounce this verdict". If this is the case, the judges are far from making decisions, intentionally or not, especially those disturbing to the public. It is the same direction that distinguishes the judiciary in Indonesia from the courts of other countries. In Indonesia, it is obligatory to conduct justice in the name of God. In other countries, it may be the other way around.

The religious values that arise project that Indonesian law science recognizes God's law and natural law, ethical law, and philosophical law in the life of the state. Implementing these values can be realized by applying these legal values as a source of motivation for Indonesian

\footnotetext{
35 Reski Anwar, "ANALISIS KOMPARATIF SANKSI TINDAK PIDANA PADA HKUM PIDANA ISLAM DENGAN HUUKUM POSITIF”, Asy-Syar'iyyah 3, no. 2 (2018): 23-46, 30, DOI : 10.32923/asy.v3i2.770.

${ }^{36}$ Moh Khasan, "PRINSIP-PRINSIP KEADILAN HUKUM DALAM ASAS LEGALITAS HUKUM PIDANA ISLAM", Jurnal RechtsVinding 6, no. 1 (2017): 109-124, 110, DOI: http://dx.doi.org/10.33331/rechtsvinding.v6i1.133.

37 Barda Nawawi Arief, Pendekatan Keilmuan dan Pendekatan Religius Dalam Rangka Optimalisasi dan Reformasi Penegakan Hukum (Pidana) Di Indonesia (Semarang: Universitas Diponegoro, 2011), 8.

38 Ibid.

${ }^{39}$ Ibid.

${ }^{40} \mathrm{http}$ ://www.hukumonline.com/berita/baca/lt55a26de809417/irah-irah--kepala-putusan-yang-bermakna-sumpah accessed on March 22, 2021.

${ }^{41}$ Ibid.
} 
legal science development. An outline can be drawn from the perspective of religious justice guided by Pancasila, which can be interpreted as contained in the 53 September 2019 edition of the Criminal Code Draft. Referring to this article, the judge must be wiser in deciding every case to align with God's guidance and the law.

\section{Conclusion}

Religious Justice that is in the value of Pancasila is formulated into the reform of criminal justice law, which contains a demand that people treat each other according to their rights and obligations. This treatment is not indiscriminate or favouritism; rather, all people are treated equally according to their rights and obligations. With the analysis stated above, it is only natural that the concept of "religious justice" in the reform of the criminal law/criminal law draft Article 53 paragraph (2), so that the formulation of the new provisions reads; If in enforcing law and justice as referred to in paragraph (1) there is a conflict between legal certainty and justice, the judge is obliged to prioritize justice. The above recommendation is put forward because the explanation of Article 53 paragraph (2) states that justice and legal certainty are two legal objectives that are often inconsistent with one another and difficult to avoid in legal practice. A legal regulation fulfils more demands for legal certainty, the greater the possibility that the aspect of justice will be pressed. In practice, these imperfections of legal regulations can be overcome by providing interpretations of these legal regulations regarding concrete events. If in the application of a concrete incident, justice and legal certainty are mutually urgent, the judge, as far as possible, prioritizes justice over legal certainty.

\section{A. Journal}

\section{REFERENCES}

Ali, Mahrus. "FONDASI ILMU HUKUM BERKETUHANAN: ANALISIS FILOSOFIS TERHADAP ONTOLOGI, EPISTEMOLOGI, DAN AKSIOLOGI", Pandecta 11, no. 2. (2016): 124-135, DOI: 10.15294/pandecta.v11i2.7844.

Anwar, Reski. "ANALISIS KOMPARATIF SANKSI TINDAK PIDANA PADA HUKUM PIDANA ISLAM DENGAN HUKUM POSITIF”, Asy-Syar'iyyah 3, no. 2, 2018: 23-46, DOI: 10.32923 /asy.v3i2.770

Ariyanti, Vivi. "PEMBAHARUAN HUKUM PIDANA DI INDONESIA YANG BERKEADILAN GENDER DALAM RANAH KEBIJAKAN FORMULASI, APLIKASI, DAN EKSEKUSI”. Halu Oleo Law Review 3, no. 2, 2019: 178-195, DOI: 10.33561/holrev.v3i2.8654. 181

Erfandi. "IMPLEMENTASI NILAI-NILAI PANCASILA DALAM PEMBANGUNAN SISTEM HUKUM PIDANA DI INDONESIA" Jurnal Ilmiah Pendidikan Pancasila dan Kewarganegaraan 1, no. 1, 2016: 23-32, DOI: 10.17977/jippk.v1i1.5933.

Faisal, Rustamaji. "PERSPEKTIF HUKUM PIDANA DALAM POLEMIK PENGAJUAN SUMPAH ADVOKAT: TELAAH PUTUSAN MAHKAMAH KONSTITUSI NOMOR 35/PUU XVII/2018 ATAS SURAT KETUA MAHKAMAH AGUNG RI NOMOR 73/KMA/HK.01/IX/2015", Jurnal Hukum Ius Quia Iustum 27, no. 3, 2020: 458-450, DOI: 10.20885/iustum.vol27.iss3.art2

Faisal. "MEMBANGUN POLITIK HUKUM ASAS LEGALITAS DALAM SISTEM HUKUM PIDANA INDONESIA", Jurnal Hukum Ius Quia Iustum 21, no. 1, 2014: 8195, DOI : 10.20885/iustum.vol21.iss1.art5.

Farikhah, Mufatikhatul, "KONSEP JUDICIAL PARDON (PEMAAFAN HAKIM) DALAM MASYARAKAT ADAT DI INDONESIA”, Jurnal Media Hukum 25, no. 1, 2018: 81-92, DOI: 10.18196/jmh.2018.0104.81-92 
Khasan, Moh. "PRINSIP-PRINSIP KEADILAN HUKUM DALAM ASAS LEGALITAS HUKUM PIDANA ISLAM”, Jurnal RechtsVinding 6, no. 1, 2017: 109-124, DOI: 10.33331/rechtsvinding.v6i1.133.

Maulidah, K., Jaya, N. S. P. "KEBIJAKAN FORMULASI ASAS PERMAAFAN HAKIM DALAM UPAYA PEMBAHARUAN HUKUM PIDANA NASIONAL," Jurnal Pembangunan Hukum Indonesia 1, no. 3, 2019: 281-293, DOI: 10.14710/jphi.v1i3.281293.

Muhammad. "BIOMIJURIDIKA: PEMIKIRAN ILMU HUKUM PIDANA BERKETUHANAN DARI BARDA NAWAWI ARIEF”, Undang: Jurnal Hukum 2, no. 1, 2019: 193-223, DOI: 10.22437/ujh.2.1.193-223.

Putri, Yulita Damar., Putri, Ni Putu M. E Purwani, Sagung. "URGENSI PEMBAHARUAN HUKUM PIDANA DI INDONESIA". Kertha Wicara : Journal Ilmu Hukum 9, no. 8, 2020: 1-13.

Rahayu, Derita Prapti. "AKTUALISASI PANCASILA SEBAGAI LANDASAN POLITIK HUKUM INDONESIA”, Yustitia 4, no. 1, 2015: 190-202, DOI: 10.20961/yustisia.v4i1.

Satria, Hariman. "RESTORATIVE JUSTICE: PARADIGMA BARU PERADILAN PIDANA". Jurnal Media Hukum 25, no. 1, 2018: 111-123, DOI: 10.18196/jmh.2018.0107.111-123

Tongat. "PANCASILA SEBAGAI DASAR FALSAFAH NEGARA DAN MAKNA FILOSOFISNYA DALAM PEMBAHARUAN HUKUM PIDANA NASIONAL", Masalah-masalah Hukum 41, no. 3, 2012: 399-406, DOI: 10.14710/mmh.41.3.2012.399406.

Utama, Tody Sasmitha Jiwa. "HUKUM YANG HIDUP DALAM RANCANGAN KITAB UNDANG-UNDANG HUKUM PIDANA (KUHP): ANTARA AKOMODASI DAN NEGASI", Masalah-Masalah Hukum 49, no. 1, 2020: 14-25, DOI: $10.14710 / \mathrm{mmh} .49 .1 .2020 .14-25$.

Wahyuningsih, Sri Endah. "URGENSI PEMBAHARUAN HUKUM PIDANA MATERIEL INDONESIA BERDASARKAN NILAI-NILAI KETUHANAN YANG MAHA ESA”. Jurnal Pembaharuan Hukum 1, no. 1, 2014: 17-23, DOI: 10.26532/jph.v1i1.1457

Yudianto, Otto. "KARAKTER HUKUM PANCASILA DALAM PEMBAHARUAN HUKUM PIDANA INDONESIA”, DIH: Jurnal Ilmu Hukum 12, no. 23, 2016: 35-44, DOI: $10.30996 /$ dih.v12i23.890.

\section{B. Books}

Arief, Barda Nawawi. Beberapa Aspek Pengembangan Ilmu Hukum Pidana (Menyongsong Generasi Baru Hukum Pidana Indonesia). Semarang: Fakultas Hukum Universitas Diponegoro, 1994.

Arief, Barda Nawawi. Ilmu Huku Pidana Integralistik (Pemikiran Integratif dalam Hukum Pidana). Semarang: Penerbit Pustaka Magister, 2015.

Arief, Barda Nawawi. Ilmu Hukum Pidana Integralistik (Pemikiran Integratif dalam Hukum Pidana). Semarang: Pustaka Magister, 2015.

Arief, Barda Nawawi. Kapita Selekta Hukum Pidana. Bandung: Citra Aditya Bakti, 2003.

Arief, Barda Nawawi. Masalah Penegakan Hukum dan Kebijakan Hukum Pidana dalam Penanggulangan Kejahatan. Jakarta: Penerbit Kencana, 2008.

Arief, Barda Nawawi. Pendekatan Keilmuan dan Pendekatan Religius Dalam Rangka Optimalisasi dan Reformasi Penegakan Hukum (Pidana) Di Indonesia. Semarang: Badan Penerbit Universitas Diponegoro, 2012.

Arief, Barda Nawawi. Pendekatan Keilmuan dan Pendekatan Religius Dalam Rangka Optimalisasi dan Reformasi Penegakan Hukum (Pidana) Di Indonesia. Semarang: Badan Penerbit Universitas Diponegoro, 2011. 
Faisal. Menerobos Hukum Positivisme. Yogyakarta: Rangkang-Education, 2010.

Faisal. Politik Hukum Pidana. Tangerang: Rangkang Education, 2020.

Hazairin, Demokrasi Pancasila, (Jakarta, Bina Aksara,1985),34, dalam Barda Nawawi Arief, Pendekatan Keilmuan dan Pendekatan Religius Dalam Rangka Optimalisasi dan Reformasi Penegakan Hukum (Pidana) Di Indonesia. Semarang: Universitas Diponegoro.

Muladi. Proyeksi Hukum Pidana Materiil Indonesia Di Masa Datang. Semarang: fakultas Hukum Universitas Diponegoro, 1990.

Soekanto, Soerjono., Mamudji, Sri Penelitian Hukum Normatif. Jakarta: Raja Grafindo Persada, 2004.

Sudarto. Suatu Dilemma Dalam Pembaharuan Sistim Pidana Indonesia. Semarang: Fakultas Hukum Universitas Diponegoro, 1979.

\section{Regulations}

Academic Draft Draft Law on Criminal Code (KUHP).

Republic of Armenia Criminal

\section{Internet}

https://www.hukumonline.com/berita/baca/lt55a26de809417/irah-irah--kepala-putusan-yangbermakna-sumpah, Accessed on February 01, 2021. 